\title{
Acid Treatments of Montmorillonite-rich Clay for Fe Removal Using a Factorial Design Method
}

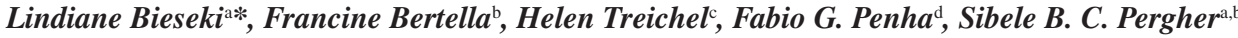 \\ aPrograma de Pós-graduação em Ciências e Engenharia de Materiais - PPGCEM, \\ Universidade Federal do Rio Grande do Norte - UFRN, \\ Av. Senador Salgado Filho, 3000, CEP 59078-970, Natal, RN, Brasil \\ ' Instituto de Química - IQ, Universidade Federal do Rio Grande do Norte - UFRN, \\ Av. Senador Salgado Filho, 3000, CEP 59078-970, Natal, RN, Brasil \\ ${ }^{\mathrm{c}}$ Universidade Federal da Fronteira Sul-UFFS, Av. Dom João Hoffman, 313, \\ CEP 99700-000, Erechim, RS, Brasil \\ ${ }^{\mathrm{d} I n s t i t u t o}$ Federal de Educação, Ciência e Tecnologia do Rio Grande do Norte - IFRN, \\ CEP 59900-000, Pau dos Ferros, RN, Brasil
}

Received: September 19, 2012; Revised: April 9, 2013

\begin{abstract}
Montmorillonite clays are of great interest for industrial processes such as catalysis and adsorption. The textural properties of clays can be modified in an attempt to increase their uses. This paper describes the acid treatment of natural montmorillonite clay. The materials were characterized using X-ray diffraction (XRD), atomic absorption spectroscopy (AA) and BET surface area measurements. Three different acids $\left(\mathrm{HCl}, \mathrm{HNO}_{3}\right.$ and $\mathrm{H}_{2} \mathrm{SO}_{4}$ ) were tested, and $\mathrm{HCl}$ and $\mathrm{H}_{2} \mathrm{SO}_{4}$ were more efficient for removing Fe from the clay. The results indicate that $\mathrm{HCl}$ better preserves the material structure because less $\mathrm{Al}$ is removed. A central composite design (CCD) $2^{2}$ was applied to evaluate the treatment using $\mathrm{HCl}$. The temperature and concentration presented positive effects on the removal of $\mathrm{Fe}, \mathrm{Al}$ and $\mathrm{Mg}$. Combinations of the $\mathrm{HCl}$ acid solution concentration and temperature, such as $4 \mathrm{~mol} \cdot \mathrm{L}^{-1} / 50{ }^{\circ} \mathrm{C}$ and 1 mol. $\mathrm{L}^{-1} / 75^{\circ} \mathrm{C}$, assured that Fe was removed with less damage to the structure.
\end{abstract}

Keywords: acid treatment, clay, montmorillonite, Fe removal, central composite design

\section{Introduction}

Smectite clays consist of layers of two silica tetrahedral sheets surrounding a central alumina octahedral sheet. In montmorillonites, which belong to this group, isomorphic substitutions occur in which the resulting negative charge is compensated by the adsorption of hydrated cations into the interlayer region ${ }^{1,2}$. These properties are useful for different industrial applications, such as in catalysis and adsorption, and can be modified using the pillarization process with aluminum polioxocations, which provides a permanent porosity and a Lewis acid characteristic to the material ${ }^{3}$. Acid treatments also result in an increase of the porosity in clays. With increasing concentration, higher surface areas are observed and the shape of the pores is modified from the slit-shaped type to the spheroidal or bottle type ${ }^{4}$. In the acid, the activation force and the number of acidic sites increase. However, as noted by Pushpletha et al. (1999) ${ }^{5}$, the maximum increase is obtained in the intermediate acid concentration range. The authors used a maximum acidity of $1.5 \mathrm{~N}$ for the samples treated with $\mathrm{H}_{2} \mathrm{SO}_{4}$ or $\mathrm{HCl}$. The increased aggressiveness of the acid treatment decreases the catalytic activity of clays because of the impairment of the octahedral layers, which reflects a decrease in the Brönsted acidity and is higher in acid-treated materials at lower concentrations ${ }^{6}$. These treatments yield catalytic

*e-mail: lindiane.bieseki@gmail.com materials that have high porosities, surface areas, acidity and thermal stability.

The natural clays have different compositions, and the presence of some types of minerals can frequently be a problem for some applications ${ }^{7}$. For example, in pillared clays for acid-base catalysis, the presence of Fe can reduce the thermal stability ${ }^{8}$.

Acid treatments are efficient for removing Fe, but other cations, such as $\mathrm{Ca}, \mathrm{Mg}$ and $\mathrm{Na}$, can also be removed. Depending on the variables tested in the treatment, a partial or total degradation of the structure of the material can occur. The treatment using hydrochloric acid for a long period of time (days) resulted in the amorphization of the structure $^{9}$ and a decrease in the cationic exchange capacity ${ }^{4,5}$. Adsorption of methylene blue on acid-treated clay minerals confirmed reduction in layer charge. From decreased values of cation exchange capacity (CEC) upon $\mathrm{HCl}$ attack was confirmed that clay with higher content of swelling layers were more stable in $\mathrm{HCl}^{10}$.

The resistance to acid treatment is also influenced by the mineralogical composition. Nguetnkam et al. (2011) ${ }^{11}$ observed that activation destroys preferentially smectites particles, kaolinite particles seem to be more resistant. After acid treatment the samples still exhibit $\mathrm{OH}$ stretching vibrations of kaolinite. 
Some previous studies ${ }^{5,12}$ using sulfuric acid and hydrochloric acid report reductions of approximately $75 \%$ to $40 \%$ in the $\mathrm{Fe}_{2} \mathrm{O}_{3}$ content, depending on the type of acid used and the temperature of the treatment. Higher concentrations and higher temperatures result in greater removals. Sulfuric acid removes a higher percentage of iron compared to the same conditions in $\mathrm{HCl}$. The parameters, such as acid concentration, contact time ${ }^{13,14}$, clay/acid ratio $^{13}$ and temperature ${ }^{14}$, were studied and applied to an oil cleaning process ${ }^{13-15}$. Acid treatments were also used during the catalytic synthesis for the benzylation of benzene with similar activity of commercial clays (K10 and KSF) ${ }^{4}$.

Those K10 and KSF commercial montmorillonite-rich clays, obtained by treatment with sulfuric acid at different temperatures, were used during the pillarization process ${ }^{16}$. The KSF clay that was obtained using a soft treatment exhibited a higher adaptability for the pillarization process. Therefore, an acid treatment study seems necessary, and the optimization of the experimental parameters is crucial for obtaining materials with low Fe levels while maintaining their structural integrity. These materials might then be used in their activated or pillared forms.

The main aim of this work is to test different acids during the treatment of a selected iron-rich montmorillonitic clay and then optimize the removal of Fe without structural degradation by using the most effective acid and adjusting the temperature and acid concentrations. A factorial design tool was used for this purpose.

\section{Material and methods}

\subsection{Materials}

The natural montmorillonite clay was supplied by Colorminas Colorifício e Mineração S/A, Içara, Brazil, and was called Clay A.

The material was treated with sulfuric acid P.A. $98 \%$ (Quimex), hydrochloric acid P.A. 37\% (Vetec) and nitric acid P.A. 65\% (Quimex).

\subsection{Leaching using different acids.}

The samples were treated with the three different acids, which were each at a concentration of 4 mol.L $\mathrm{L}^{-1}$. The reaction time was $6 \mathrm{~h}$, and the temperature was $50^{\circ} \mathrm{C}$. The solid/liquid ratio was $1 \mathrm{~g}$ of solid to $30 \mathrm{~mL}$ of solution. All of the treated samples were washed until the $\mathrm{pH} \geq 5$, and they were dried at $95^{\circ} \mathrm{C}$ for $12 \mathrm{~h}$.

\subsection{Experimental design for leaching with $\mathrm{HCl}$}

After selecting the acid (hydrochloric acid), a central composite design (CCD) $2^{2}$ was constructed. The independent variables studied were temperature $\left(25\right.$ and $\left.75^{\circ} \mathrm{C}\right)$ and $\mathrm{HCl}$ concentration ( 1 and 7 mol. $\mathrm{L}^{-1}$ ) (Table 1$)$. The reaction time was fixed at $6 \mathrm{~h}$, and the Clay/ $\mathrm{HCl}$ ratio was maintained at $1 \mathrm{~g}$ to $30 \mathrm{~mL}$. The data were statistically analyzed using the Statistica 6.0 software package (Statsoft Inc, Tulsa, USA).

\subsection{Characterization of samples}

The obtained materials were characterized using X-ray diffraction (XRD) and specific surface area adsorption (BET) and X-ray fluorescence (XRF). The liquid phase was analyzed using atomic absorption spectroscopy (AA) to quantify the extracted amounts of $\mathrm{Mg}, \mathrm{Fe}$ and $\mathrm{Al}$.

The X-ray diffraction measurements were performed on a Siemens D5000 diffractometer equipped with a $\mathrm{Ni}$ filter and a $\mathrm{Cu} \mathrm{K} \alpha$ X-ray source $(\lambda=1.54 \AA)$ interval of $2 \theta=2^{\circ}$ to $65^{\circ}$ and scanning pace of $0.02^{\circ}$. A Varian model AA spectrometer was used for the atomic absorption measurements. The surface area measurements were performed using nitrogen adsorption data employing a QuantaChrome NovaWin 2 instrument. The samples were analyzed by infrared spectroscopy using a FT-IR Bruker alpha-p equipment without pretreatment.

\section{Results and Discussion}

\subsection{Leaching with different acids}

Table 2 presents the chemical analysis data (FRX) of Clay A. The sample presents a low concentration of $\mathrm{Fe}_{2} \mathrm{O}_{3}$ $(2.37 \%)$. Fe in smectite clays can be as isolated oxides or in an isomorphic substitution in the crystal network ${ }^{8}$. The material contained montmorillonite $\left(2 \theta=5.8^{\circ} ; 17.7^{\circ}\right.$; $19.8^{\circ}$ and $35.1^{\circ}$ ), quartz and mica (see Figure 1).

After the leaching treatment, the recovered material and the control sample were analyzed using XRD. Figure 1 presents the results of leaching with different acids at a concentration of $4 \mathrm{~mol} . \mathrm{L}^{-1}$ at $50{ }^{\circ} \mathrm{C}$. It was observed that the intensity of the 001 peak decreased. This loss of intensity likely occurs because of a lamellar distortion that causes a partial decomposition of the structure.

Table 1. Matrix of CCD $2^{2}$ (real and coded values) used and responses in terms of mass of cations dissolved during acid treatment.

\begin{tabular}{cccccc}
\hline Run & $\mathbf{T}\left({ }^{\circ} \mathbf{C}\right)$ & {$\left[\right.$ ] $\mathbf{~ m o l .} . \mathbf{L}^{-\mathbf{1}}$} & $\mathbf{M g}^{2+}$ & $\mathbf{F e}^{2+}$ & $\mathbf{A l}^{3+}$ \\
\hline 1 & $25(-1)$ & $1(-1)$ & 3.61 & 0.66 & 2.68 \\
2 & $25(-1)$ & $7(+1)$ & 3.72 & 0.87 & 3.34 \\
3 & $75(+1)$ & $1(-1)$ & 4.97 & 3.27 & 10.13 \\
4 & $75(+1)$ & $7(+1)$ & 10.96 & 9.93 & 26.76 \\
$5 *$ & $50(0)$ & $4(0)$ & 5.98 & 4.82 & 4.05 \\
$6^{*}$ & $50(0)$ & $4(0)$ & 6.05 & 5.04 & 4.58 \\
$7 *$ & $50(0)$ & $4(0)$ & 5.52 & 4.31 & 3.73 \\
\hline
\end{tabular}

* central points.

Table 2. Clay A mass composition (wet sample).

\begin{tabular}{cc}
\hline Compound & Mass (\%) \\
\hline $\mathrm{SiO}_{2}$ & 63.29 \\
$\mathrm{Al}_{2} \mathrm{O}_{3}$ & 17.26 \\
$\mathrm{Fe}_{2} \mathrm{O}_{3}$ & 2.37 \\
$\mathrm{CaO}$ & 2.47 \\
$\mathrm{Na}_{2} \mathrm{O}$ & 0.15 \\
$\mathrm{~K}_{2} \mathrm{O}$ & 0.38 \\
$\mathrm{MnO}$ & 0.45 \\
$\mathrm{TiO}_{2}$ & 0.14 \\
$\mathrm{MgO}$ & 5.08 \\
$\mathrm{P}_{2} \mathrm{O}_{5}$ & 0.02 \\
$\mathrm{LOI}$ & 8.37 \\
\hline
\end{tabular}


In addition, the 001 peak is shifted. Before the acidic treatment, the $d_{001}$ of the clay was $15.12 \AA$. After treatment with $\mathrm{HCl}, \mathrm{H}_{2} \mathrm{SO}_{4}$ and $\mathrm{HNO}_{3}$, the $\mathrm{d}_{001}$ changed to 12.56 , 14.73 and $12.60 \AA$, respectively. This peak shift is more pronounced after treatment with hydrochloric and nitric acids, and it indicates a decrease of the interlayer region. Table 3 presents the the amount of metal removed after acid leaching.

The decrease in the interlayer region resulting from the acid treatments with $\mathrm{HCl}$ and $\mathrm{HNO}_{3}$ can be attributed to the exchange of the $\mathrm{Ca}^{2+}$ cation with $\mathrm{H}^{+}\left(\mathrm{H}_{3} \mathrm{O}^{+}\right)$. Pushpletha et al. $(2005)^{5}$ reported that the basal spacing of samples treated with $\mathrm{H}_{2} \mathrm{SO}_{4}$ also decreased. In our samples, a re-hydration process may have occurred because with the acid treatment, the samples lose only approximately $20 \%$ of their swelling capacity compared to natural clay ${ }^{17}$. All of the acids removed cations, namely $\mathrm{Al}, \mathrm{Mg}$ and $\mathrm{Fe}$, from the octahedral layer of the clay. After the acid treatment of metakaolinite and natural kaolinite, Sabu et al. (1999) ${ }^{18}$ observed that $\mathrm{H}_{2} \mathrm{SO}_{4}$ was more efficient in the removal of Fe. In montmorillonite-rich clays, $\mathrm{H}_{2} \mathrm{SO}_{4}$ strongly removed the $\mathrm{Al}^{3+}$ species, which resulted in partial degradation of the structure ${ }^{5,12}$. The removal of magnesium was similar for all of the different acid treatments. Finally, nitric acid did not remove Fe from the material.

All of the samples that were treated with different acids were analyzed using $\mathrm{N}_{2}$ adsorption measurements, and Table 4 presents the measured surface areas. As expected, the surface areas increased after the acid treatment, which is a probable consequence of removing cations from the clay structure, thereby promoting porosity.

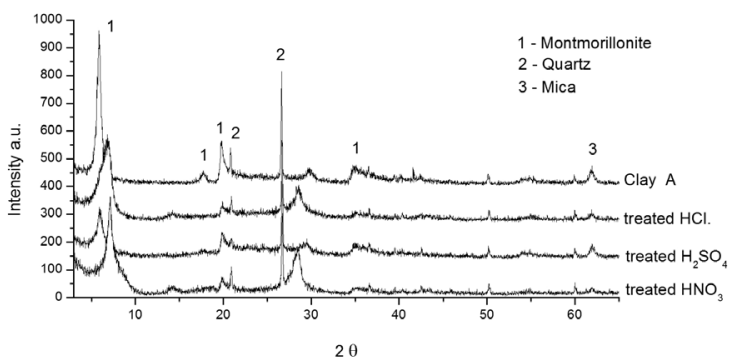

Figure 1. Diffractogram of Clay A treated with $\mathrm{HCl}, \mathrm{H}_{2} \mathrm{SO}_{4}$ and $\mathrm{HNO}_{3}$ with $4 \mathrm{~mol} / \mathrm{L}$ at $50{ }^{\circ} \mathrm{C}$ for $6 \mathrm{~h}$.

Table 3. Mass of cations dissolved during acid treatment at a concentration of $4 \mathrm{~mol} \cdot \mathrm{L}^{-1}$ at $50{ }^{\circ} \mathrm{C}$ for $6 \mathrm{~h}$ (mg of cation/g of clay).

\begin{tabular}{cccrc}
\hline Acids & $\mathbf{F e}^{2+}$ & $\mathbf{M g}^{2+}$ & $\mathbf{C a}^{2+}$ & $\mathbf{A l}^{3+}$ \\
\hline $\mathrm{HCl}$ & 5.03 & 6.05 & 15.33 & 4.58 \\
$\mathrm{H}_{2} \mathrm{SO}_{4}$ & 6.29 & 6.75 & 0.33 & 12.68 \\
$\mathrm{HNO}_{3}$ & 1.76 & 6.61 & 13.37 & 9.00 \\
\hline
\end{tabular}

Table 4. Surface areas (BET) for samples leached with $\mathrm{HCl}, \mathrm{H}_{2} \mathrm{SO}_{4}$ and $\mathrm{HNO}_{3}$ with 4 mol.L $\mathrm{L}^{-1}$ at $50{ }^{\circ} \mathrm{C}$ for $6 \mathrm{~h}$.

\begin{tabular}{cc}
\hline Sample & $\mathbf{S}_{\text {BET }}\left(\mathbf{m}^{2} / \mathbf{g}\right)$ \\
\hline Clay A & 63 \\
Leached $\mathrm{HCl}$ & 124 \\
Leached $\mathrm{H}_{2} \mathrm{SO}_{4}$ & 138 \\
Leached $\mathrm{HNO}_{3}$ & 99 \\
\hline
\end{tabular}

The increase of in the specific surface area has been reported for different materials, for example, KSF and K10 clays that were treated with sulfuric acid ${ }^{19}$. For the KSF clay, the surface area values were lower $\left(9 \mathrm{~m}^{2} / \mathrm{g}\right)$ than for K10 clay, and micropores were not observed, which reveals that the structural elements ( $\mathrm{Al}, \mathrm{Fe}$ and $\mathrm{Mg}$ ) were weakly extracted. This clay was treated at room temperature. In contrast, the acidic treatment of the K10 clay was stronger and performed at higher temperatures, which resulted in the extraction of Al. The K10 clay presented a large surface area $\left(229 \mathrm{~m}^{2} / \mathrm{g}\right)$ with a major contribution from the mesopores.

\subsection{Experimental design for leaching with $\mathrm{HCl}$}

The central composite design (CCD) using hydrochloric acid was constructed to verify the removal of $\mathrm{Fe}$ and other species. Because the sample treated with $\mathrm{HCl}$, at first, have a smaller disorganization, than the sample treated with $\mathrm{H}_{2} \mathrm{SO}_{4}$. Atomic absorption spectroscopy was used to determine the amounts of $\mathrm{Mg}^{2+}, \mathrm{Fe}^{2+}$ and $\mathrm{Al}^{3+}$ in the liquid phase. Table 1 presents the evaluated variables, the experimental results and the response to the acid treatment in terms of cation removal (mg of cation/g of clay).

The main and interaction effects of each evaluated variable are presented in Figure $2 . \mathrm{Mg}$ can be present in the interlayer space of the clay structure, but it can also be exchangeable or isomorphically substituted into the crystalline network ${ }^{1}$. The Pareto chart presented in Figure $2 \mathrm{a}$ shows that either an increase in temperature or acid concentration enhances the removal of $\mathrm{Mg}^{2+}$. However, the effect of temperature appears to be more relevant. In fact, at low temperatures, the removal is incipient, irrespective of the acid concentration.

The effects of temperature and acid concentration on the removal of $\mathrm{Fe}$ are shown in the Pareto chart presented in Figure 2b, and one can observe that the concentration of acid enhances the removal of $\mathrm{Fe}$ when the temperature is higher than $30{ }^{\circ} \mathrm{C}$. This result is in agreement with previously reported results ${ }^{13}$ that revealed that the removal of $\mathrm{Fe}^{2+}$ does not occur when temperature is $30^{\circ} \mathrm{C}$ or below.

During the extraction of aluminum, both parameters (temperature and concentration) showed significant (main and interactive) effects, as observed in Figure 2c. Higher temperatures and acid concentrations enhance the removal of $\mathrm{Al}^{3+}$, but the temperature exerts a major influence on the evaluated response. As observed with the other species, an increase in the acid concentration during the test performed at room temperature did not promote a strong extraction of $\mathrm{Al}^{3+}$.

Table 5 presents the empirical models that predict the removal of cations ( $\mathrm{mg}$ of cation/g of clay) as a function of temperature and $\mathrm{HCl}$ concentration. One can observe, based on the variance analysis presented in Table 6 , that the coded models related to the removal of $\mathrm{Mg}^{2+}$ and $\mathrm{Fe}^{2+}$ were validated. However, the model related to the removal of $\mathrm{Al}^{3+}$ was not validated considering the $95 \%$ confidence level. In this situation, an analysis of the Pareto chart of effects should be followed. The determination coefficients were $99 \%, 96 \%$ and $83 \%$ for the $\mathrm{Mg}^{2+}, \mathrm{Fe}^{2+}$ and $\mathrm{Al}^{3+}$ cations, respectively.

Infrared analyses of the natural and leached samples were performed (Figure 3 ) to examine the influence of the acid treatments on the crystalline compositions. The bands at 
3405 and $1635 \mathrm{~cm}^{-1}$ (adsorbed water) become more diffuse when the severity of the treatment is increased ${ }^{14}$.

The natural and acid treated samples exhibit absorption bands that are characteristic of dioctahedral smectites (3629 $\mathrm{cm}^{-1}$ - stretching vibration of Al-OH-Al, and $920 \mathrm{~cm}^{-1}-$ deformation vibration of $\left.\mathrm{Al}-\mathrm{OH}-\mathrm{Al}\right)^{5,14}$. These bands and the band observed at $1116 \mathrm{~cm}^{-1}(\mathrm{Al}-\mathrm{OH})^{4}$ decrease after $\mathrm{Al}$ is removed during the acid treatment. The absorption bands also become more diffuse when the severity of the treatment is increased. The absorption band at $1116 \mathrm{~cm}^{-1}$ from the samples treated with the 7 mol. $\mathrm{L}^{-1}$ solution at $75^{\circ} \mathrm{C}$ was almost eliminated. This result indicates that the acidic

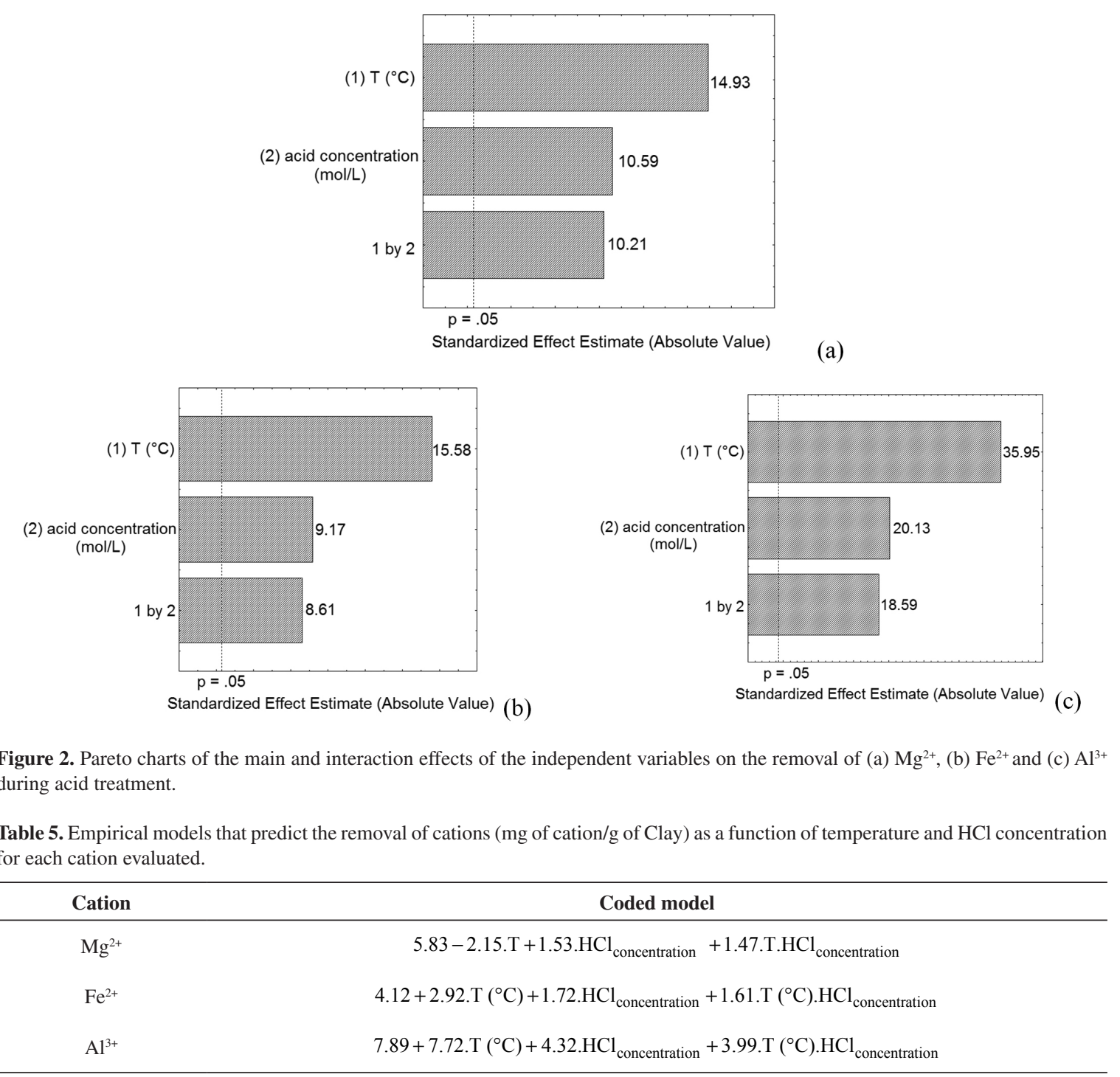

Table 6. Analysis of variance for each model presented in Table 5.

\begin{tabular}{llcccc}
\hline \multicolumn{1}{c}{ Cation } & & Sum of squares & Degrees of freedom & Mean of squares & F calculated \\
\hline $\mathrm{Mg}^{2+}$ & Regression & 36.44 & 3.00 & 12.15 & 217.01 \\
& Residues & 0.17 & 3.00 & 0.06 & \\
$\mathrm{Fe}^{2+}$ & Total & 36.60 & 6.00 & & 26.31 \\
& Regression & 56.25 & 3.00 & 0.71 & 5.01 \\
& Residues & 2.14 & 3.00 & & \\
$\mathrm{Al}^{3+}$ & Total & 58.38 & 6.00 & 125.58 & \\
& Regression & 376.74 & 3.00 & 25.07 & \\
& Residues & 75.21 & 3.00 & & \\
\end{tabular}


treatment preferentially attacks the octahedral layers of the clay. However, the intensity decreases of the $997 \mathrm{~cm}^{-1}(\mathrm{Si}-$ O-Si stretching) and $518 \mathrm{~cm}^{-1}$ (Si-O deformation) bands after leaching indicates that tetrahedral structure was also affected by the acid treatment ${ }^{4}$.

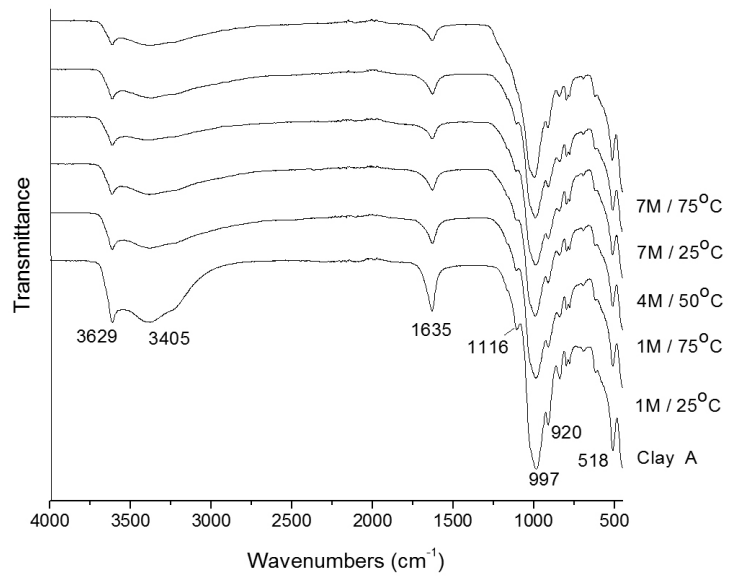

Figure 3. FTIR spectra of leached samples.

Table 7. BET surface areas for samples treated with $\mathrm{HCl}$ using the experimental design methodology.

\begin{tabular}{cccc}
\hline Run & $\begin{array}{c}\mathbf{S}_{\text {BET }} \\
\left(\mathbf{m}^{2} / \mathbf{g}\right)\end{array}$ & $\begin{array}{c}\text { Temperature } \\
\left({ }^{\circ} \mathbf{C}\right)\end{array}$ & $\begin{array}{c}\text { Concentration } \\
\left(\mathbf{m o l} . L^{-1}\right)\end{array}$ \\
\hline 1 & 73 & 25 & 1 \\
2 & 69 & 25 & 7 \\
3 & 126 & 75 & 1 \\
4 & 176 & 75 & 7 \\
$6 *$ & 124 & 50 & 4 \\
\hline
\end{tabular}

* central point.

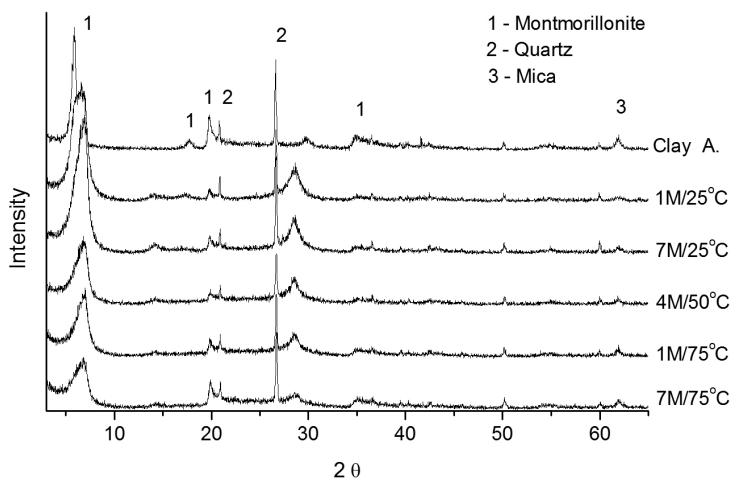

Figure 4. XRD patterns of Clay A and samples treated with $\mathrm{HCl}$ at concentrations of 1,4 and 7 mol. $\mathrm{L}^{-1}$ at 25,50 and $75^{\circ} \mathrm{C}$ for $6 \mathrm{~h}$.
Table 7 presents the surface area values for the samples treated for $6 \mathrm{~h}$ with $\mathrm{HCl}\left(1,4\right.$ and 7 mol.L $\left.\mathrm{L}^{-1}\right)$ at 25, 50 and $75^{\circ} \mathrm{C}$. Previous reports ${ }^{4,5,13}$ indicate that an increases in the acid concentration promotes the removal of cations from the tetrahedral and octahedral layers, which results in an increase of the surface areas. Before treatment, the clay presents a surface area of $63 \mathrm{~m}^{2} / \mathrm{g}$. In this work, an increase in the surface area was not observed for the samples treated at $25^{\circ} \mathrm{C}$. The tendency for the surface area to increase was confirmed only at higher temperatures, even when using diluted acid solutions ( 1 mol. $\left.\mathrm{L}^{-1}\right)$.

Changes in the mineralogical composition, which were revealed in the XRD measurements presented in Figure 4, are in agreement with the variations in the specific surface area data. All of the samples treated at $25^{\circ} \mathrm{C}$ present almost constant structural features because the removal of $\mathrm{Fe}$ and $\mathrm{Al}$ is low. The displacement of the 001 reflection (from 15.12 $\AA$ in the natural clay to $13.4 \AA$ and $12.83 \AA$ for the samples treated with 1 and $7 \mathrm{~mol} / \mathrm{L}$, respectively) is likely caused by a $\mathrm{Ca}^{2+}$ cationic exchange, as noted in a previous study ${ }^{5}$.

At higher temperatures, a significant decrease in the intensity of the diffraction peaks is observed. The major decrease in the diffraction peak intensity occurs after treating with 7 mol. $\mathrm{L}^{-1}$ of $\mathrm{HCl}$ at $75^{\circ} \mathrm{C}$.

\section{Conclusions}

Sulfuric and hydrochloric acids were efficient in the removal of $\mathrm{Fe}$ from the montmorillonite-rich clay used in this work. These acids also promoted the extraction of the $\mathrm{Al}$ and $\mathrm{Ca}$ species, respectively. In contrast, the use of nitric acid for the removal of $\mathrm{Fe}$ was inefficient. The acid treatment enhanced the specific surface area of the material, thereby revealing the partial degradation of the structure. Also evidenced by the decrease in intensity of the diffraction peaks 001 in samples treated. The use of the experimental design methodology might be useful in helping to define such conditions, and to explain the influence of temperature and $\mathrm{HCl}$ acid concentration on the extraction of $\mathrm{Fe}, \mathrm{Mg}$ and $\mathrm{Al}$. The temperature has a more effect on the removal of $\mathrm{Al}$ compared removal of $\mathrm{Fe}$ and $\mathrm{Mg}$.

The combinations 4 mol. $\mathrm{L}^{-1} \mathrm{HCl} / 50{ }^{\circ} \mathrm{C}$ and 1 mol.L ${ }^{-1}$ $\mathrm{HCl} / 75^{\circ} \mathrm{C}$ assured the best results for removal of $\mathrm{Fe}$ without affecting the structure of the material.

\section{Acknowledgements}

The authors thank URI - Campus Erechim, Colorminas Colorificio e Mineração S/A, and CNPq for financial support of this work and scholarships. 


\section{References}

1. Gomes CF. Argilas: O que são e para que servem. Lisboa: Fundação Galouste Gulbenkian; 1988.

2. Pergher SBC, Corma A and Fornes V. Materiales Laminares Pilareados: Preparación y Propiedades Quimica Nova. 1999a; 22:693-709. http://dx.doi.org/10.1590/S010040421999000500013

3. Pergher SBC, Corma A and Fornes V. Preparación y Propiedades de una Arcilla Montmorillonita Pilareada con Polihidroxicationes de Aluminio. Quimica Nova. 1999b; 22:649-653. http://dx.doi.org/10.1590/S010040421999000500004

4. Kumar P, Jasra RV and Bhat TSG. Evolution of porosity and surface acidity in montmorillonita clay an acid activation, Industrial e Engineering Chemistry Research. 1995; 34:14401448. http://dx.doi.org/10.1021/ie00043a053

5. Pushpletha P, Rugmini S and Lalithambika M. Correlation between surface properties and catalytic actividy. Applied Clay Science. 2005; 30:141-153. http://dx.doi.org/10.1016/j. clay.2005.03.011

6. Komadel P. Chemically modified smectites. Clay Minerals. 2003; 38:127-138. http://dx.doi.org/10.1180/0009855033810083

7. Araújo CS and Silva LRD. Influência da Calcinação sobre a Remoção de Ferro da Caulinita e Ilita e seus Efeitos sobre a Acidez. Quimica Nova. 2003; 26:161-164. http://dx.doi. org/10.1590/S0100-40422003000200003

8. Leite SQM, Colodete CHA and Dieguez LC. Extração de Ferro de Esmectita Brasileira com Emprego do Método DitionitoCitrato-Bicarbonato. Quimica Nova. 2000; 23:297-302. http:// dx.doi.org/10.1590/S0100-40422000000300002

9. Rodrigues MGF, Pereira KRO and Valenzuela-Diaz FR. Obtenção e caracterização de materiais argilosos quimicamente ativados para utilização em catálise. Cerâmica. 2006; 52:260263. http://dx.doi.org/10.1590/S0366-69132006000400008

10. Pentrák M, Czímerová A, Madejová J and Komadel P. Changes in layer charge of clay minerals upon acid treatment as obtained from their interactions with methylene blue. Applied Clay Science. 2012; 55:100-107. http://dx.doi.org/10.1016/j. clay.2011.10.012
11. Nguetnkam JP, Kamga R, Villiéras F, Ekodeck GE, Razafitianamaharavo A and Yvon J. Alteration of cameroonian clays under acid treatment. Comparison with industrial adsorbents. Applied Clay Science. 2011; 52:122-132. http:// dx.doi.org/10.1016/j.clay.2011.02.009

12. Folleto EL, Morgado AF and Porto LM. Influência do tipo de ácido usado e da sua concentração na ativação de uma argila bentonitica. Cerâmica. 2001; 47:208-211.

13. Didi MA, Makhoukhi B, Azzouz A and Villemin D. Colza oil bleaching through optimized acid activation of bentonite. A comparative study. Applied Clay Science. 2009; 42:336-344. http://dx.doi.org/10.1016/j.clay.2008.03.014

14. Christidis GE, Scott PW and Dunham AC. Acid activation and bleaching capacity of bentonites from the islands of Milos and Chios, Aegean, Greece. Applied Clay Science. 1997; 12:329347. http://dx.doi.org/10.1016/S0169-1317(97)00017-3

15. Woumfo D, Kamga R, Figueras F and Njopwouo D. Acid activation and bleaching capacity of some Cameroonian smectite soil clays. Applied Clay Science. 2007; 37:149-156. http://dx.doi.org/10.1016/j.clay.2006.12.008

16. Rossa V, Spazzini ST, Schwanke AJ, Penha FG and Pergher SCB. Pilarização de Argilas Montmorillonitas Comerciais. In: Anais $30^{a}$ Reunião Anual da Sociedade Brasileira de Química; 2007; São Paulo. São Paulo; 2007.

17. Önal M. Swelling and cation exchange capacity relationship for the samples obtained from a bentonite by acid activations and heat treatments. Applied Clay Science. 2007; 37:74-80. http://dx.doi.org/10.1016/j.clay.2006.12.004

18. Sabu KR., Sukumar R, Rekha R and Latithambika M. A comparative study on $\mathrm{H}_{2} \mathrm{SO}_{4}, \mathrm{HNO}_{3}$ and $\mathrm{HClO}_{4}$ treated metakaolinite of a natural Kaolinite as Friedel-Crafts alkylation catalyst. Catalysis Today. 1999; 49:321-326. http://dx.doi. org/10.1016/S0920-5861(98)00439-8

19. Cseri T, Békássy S, Figueras F, Cseke E, Menorval L and Dutartre R. Characterization of clay-based K catalysts and their application in Friedel-Crafts alkylation of aromatics. Applied Catalysis A: General. 1995; 132:141-155. http://dx.doi. org/10.1016/0926-860X(95)00158-1 